\title{
DIGITIZATION IN EDUCATION SYSTEM AND MANAGEMENT OF EARLY CHILDHOOD CARE EDUCATION IN NIGERIA
}

\author{
Abdullahi, Nimota Jibola Kadir ${ }^{1}$,Tijani Abdulganiyu Adebayo ${ }^{2}$ \\ Department of Educational Management, Faculty of Education. University of Ilorin, Nigeria. \\ abdullahi.njk@unilorin.edu.ng1, tijania.abdulganiy@gmail.com² \\ DOI: https://doi.org/10.37134/saecj.vol8.no2.3.2019
}

Received: 10 July 2019; Accepted: 01 November 2019; Published: 28 November 2019

\begin{abstract}
This study investigated digitization in education system and management of early childhood care education in Nigeria. The objectives of this study are to determine the relationship between collaborative learning, gamebased learning and management of early childhood care education in North-central, Nigeria. Two hypotheses were formulated and tested. Quantitative research design was used for the study. A self-designed questionnaire titled "Digitization and Management of Early Childhood Care Education Questionnaire" (DMECCEQ) was used to collect information for the study. This study focuses on public primary schools with early childhood care education in North-Central zone, Nigeria. The population of this study comprised all 2,729 head teachers and 5,529 teachers in public primary schools with early childhood care education in North-Central. Sample of 338 head teachers and 361 teachers were proportionally selected in the seven States with the use of Research Advisor (2006) table to determine the sample size of a known population, stratified random sampling technique was used to select primary school head teachers and teachers from the sample schools. This was to ensure that all categories of head teachers and teachers were given equal chance of being selected. The data collected were analyzed using t-test statistical analysis. All hypotheses were tested at the 0.05 level of significance. The result revealed that there was no significant difference between collaborative learning, game-based learning and management of early childhood care education in Nigeria. It was recommended that teachers should continue to make use of collaborative learning in order to increase pupils' motivation to learn, also make use of appropriate game-based learning for learners to have better self-management, opportunities for collaborative and inquiry-based learning in order to enhance effective management of early childhood care education in Nigeria.
\end{abstract}

Keywords: digitization, collaborative learning, management, early childhood care education, Nigeria.

\section{INTRODUCTION}

Modern teaching materials are very crucial and most preferred in the digitalize world. A modern education system uses technology to impart knowledge. Digitization of education system is an opportunity to develop a cognitive resource-based mechanism in learners and improve the skills, lifelong learning and continuous education. Digitization produces information that can be conveyed in many different methods. It brings about democracy of knowledge where education become a collaborative and self-driven enterprise. Nowadays, there are tools available to transform learning from an academic exercise to an engaging experience gamification and collaborative learning.

Early childhood care education is the education given in an educational institution to children prior to their entry to the primary school. The purpose of this level according to National Policy on Education (FRN, 2013) include the norms to effect a smooth transition from the home to the school; prepare the child for the primary school level of education; provision of adequate care and supervision for the children, while their parent are at work; 
develop a sense of cooperation and team-spirit; impart in the child the spirit of enquiry and creativity through exploration of nature, art, music and playing with toys; as well as teach the rudiments of numbers, letters, colours, shapes and the likes through play.

Management means many things to many people. In a general term, management implies the process by which group of people direct actions towards common goals. Management involves initiative and innovative actions that bring about effective change and creative problem solving by redeploying both human and material resources towards the achievement of organizational goals and objectives (John, 2014). Management is an act of making resources available and maximum utilization of these resources towards the achievement of educational goals and objectives.

Several studies have been carried out in digital education and effectiveness of early childhood education. Yousafzai, Rasheed, Rizvi, Shaheen, Ponguta and Reyes (2018) investigated the effectiveness of a youth-led early childhood care and education programme in rural Pakistan: A cluster-randomized controlled trial. Falasteen (2018) conducted the implementation of digitalization system in education in Palestine. Colombo (2016) investigated the introduction of the concept to the special sector. In addition, Colombo focused in the digitalization of educational practices: How much and what kind. Sheu and Ijaiya (2016) carried out the influence of resource availability on teachers' job performance in early childhood education. Olga (2017) conducted digitalization of education as a trend of its modernization and reforming. Phaik and Ahmad (2012) investigated education policy: A case study of digitizing education in Malaysia. Anna, Konrad and Magnus (2019) conducted surveying preschool teachers' use of digital tablets: general and technology education related findings. Online survey consisting of 20 closed and 6 open items that probed the use of digital tablet in preschools. The Survey result showed a high degree of engagement with digital tablets in preschools with activities directed toward various subject-related, social and generic skills. Rasmi, Swagakika, Sunakar (2019) conducted pre-primary education: its impact on academic achievement of the learners learning at an elementary stage in Odia language subject in Odisha. Sample of 120 elementary learners of the class consisted 60 boys and 60 girls using random sampling technique for the study. The t-test statistical analysis was used to compare the academic achievement of the learners. The findings revealed that learners learning in elementary level receiving pre-primary education do better in their oral and written in Odia language subject than the learners receiving no pre-primary education. There are several areas on digitization and management of early childhood care education that are yet to be covered by these scholars. These areas include digitization, management of teacher job performance especially early childhood care in North-central zone, Nigeria. This study on digitization and management of teachers' job performance in early childhood care education. Also, to the researchers' knowledge, there have been no researches in Nigeria so far that looked at collaborative learning, game-based learning as critical variables to measure digitization to enhance effective management of teachers' job performance in early childhood care education. Therefore, this study endeavour to fill the gaps left by the previous scholars. The following objectives have been formulated to:

a) Investigate the relationship between collaborative learning and management of early childhood care education.

b) Examine the relationship between game-based learning and management of early childhood care education 


\section{Research Hypotheses}

The following hypotheses were formulated and answered:

(1) There is no significant difference between the mean scores of head teachers and teachers on collaborative learning and management of early childhood care education.

(2) There is no significant difference between the mean scores of head teachers and teachers on game-based learning and management of early childhood care education.

\section{LITERATURE REVIEW}

\section{Digitization in education system}

Digitization in education system improves effective management of early childhood care education to operate efficiently and proactively in term of adequate supervision of learners and regular assessment of pupils' activities in the classroom. Digitization in education is the process of turning traditional methods of teaching such as paper document, sounds and more to a digital format that can be understood by pupils or students toward the achievement of educational goals and objectives (Falasteen, 2018). Digitizing is the central way of making digital representations of geographical features, storing images, creating of electronic charts by digitizing traditional paper documents, graphs or images (Cloonan \& Sanett, 2005). Digitization in this study refers to collaborative and game-based learning used by teachers to improve their job performance towards the realization of effective management of early childhood care education.

Collaborative learning is a learning method by which the teachers create a small mixed groups of pupils to help each other's learning about an academic activity in the classroom for them to achieve common goal, improve communication skills as well as selfconfidence (Grillies, 2006). This means that collaborative leaning is a method that promote the pupils ability to think positively, open to change, productive and creative. Collaborative learning is very important in the early childhood care education for the fact that, it makes learners with different upbringing or background work together to develop social skills, build trust, and gain confidence in order to achieve common goal. This method represents a significant away from the traditional teaching method of teacher centered approach in school classroom.

\section{Collaborative Learning and Management of Early Childhood Care Education}

Collaborative learning as a learning to be together with others help teachers to encourage children self-initiative and confidence. It is a learning method in which the learners help each other's learning in the direction of a common goal by increasing self-confidence, communication skills and active participation in the lesson (Grilles, 2006). Collaborative learning aid effective management of early childhood care education in that it helps to maintain a relationship skills, positive learning skills, social skills, copping with aggressive skills, copping with stress skills, problem solving skills and planning skills. In addition, collaborative learning is a learning strategy which increases motivation of the learners, improving their thinking skills, teaches them to become democratic individual as well as makes teaching-learning environment to be more entertaining for children (Nilufer, 2016). 
Collaborative learning in early childhood care education can provide many opportunities for developing communication skills such as language, interaction, empathetic skills and social skill. It could also be a strategy that could help teachers to achieve better results in their pedagogical management.

Game-based learning (GBL) simply means the act of including games in the instruction. It creates a dynamic scenario that can motivate learners to develop emotional concern and skills to learning. GBL serve as effective elements of providing a highly engaging learning environment for pupils. It has many benefits for early childhood care education because it is an effective tools in supporting children's learning and development.

\section{Game-based Learning and Management of Early Childhood Care Education}

Game-based learning serve as a fundamental needs of learning by providing children with enjoyment, motivation, passionate involvement, creativity, emotion and social interaction (Prensley, 2001). GBL is designed to balance subject matter with game play to retain and apply the subject matter to the real world in order to improve teaching and learning. GBL aid effective management of early childhood care education in such that, it serve as a motivation for children to learn, improve interaction (interpersonal relationship), provides feedback and creativity (Connolly, Boyle, MacArtur, Hainey \& Boyle, 2012).

\section{Management of Early Childhood Care Education}

Management can be seen as the process of planning, coordinating, controlling, monitoring, supervising, directing, and evaluating results in order to realize predetermined goals of organisation (Abdullahi, 2018). Management of education is the process of making resources available and maximum utilization of the resources in order to achieve stated organizational goals and objectives (Segun, 2010).

Supervision becomes imperative for monitoring the factor resources for the pursuit of maintaining standard and quality. Supervision is generally aimed at improving teaching learning situation, identifying demanding needs of the school with a view to finding appropriate solutions. Supervision is the supportive service given to teachers to upgrade their knowledge by learning and detecting what their problems are and then seeking the best method of solving them towards the realization of better learning (Abdullahi, Omosidi, Sheu \& Abdulkareem, 2016).

Assessment refers to the process of evaluating, testing and measuring the performance of learners in line with the stated educational goals and objectives (Owolabi, 2016). Assessment is a systematic process of collecting information about what students know, and are able to do in order to provide feedback to learners, parents and guardians. According to Abdullahi (2016) balance assessment system comprised of four processes that include naming, formative, interim, diagnostic and summative assessment. Formative assessment is the process of evaluating learners during instruction for the purpose of knowing the extent of teaching and learning by identifying areas of growth and development. Interim assessment used by educators during instruction for the purpose of informing and improving learning. Diagnostic assessment occur at the beginning of unit of study to find out what learners know and can do or any cause and solution to the problems faced by learners. Lastly, summative assessment used to evaluate learners programme of success at the end point of session. Regular assessment of learners enable the teacher to obtain information and feedback in order to determine the effect of instruction on learners and give necessary attention to them at each level. 


\section{Rational for Digitization in Early Childhood Care Education}

Children today are born into the world where technology has become a trend for literacy and knowledge. There is promising evidence that digitization in education system such as computer games, collaborative learning, game-based learning, implementation of portable writing aids and the likes help children to be able to develop their cognitive, social, emotional, intellectual and problem solving skills. The reason for digitization in education is to provide early childhood children with a variety of developmentally practices that encourage their independences, self-esteem and individual strengths through collaborative and game-based learning (Lin, 2006). Petersen (2015) posits that at early childhood care education level, there is need to considered and integrate educational tools such as digital tablets into early childhood education in order to bring about meaniful learning activities. Consequently, during the administration of Governor Rauf Aregbesola in Osun State, Nigeria, distributed 30,000 E-learning computer tablet otherwise known as "tablet of knowledge (Opon Imole)" for junior secondary schools students in the State. The device contains e-book library, comprising of text books, study tips, integrated text zone which contains past questions and answers, solution to standard examinations questions, and virtual classroom where comprehensive school notes with illustrations and worked examples for the 17 subjects of science, art and commercial were configured (Premium Time newspaper, 2013). Digitization in early childhood care education is one of the most pedagogical strategies to develop cognitive, affective, psychomotor and emotional skill in children.

\section{THEORETICAL FRAMEWORK}

The theoretical framework of this study is based on developmental state of children's progress theory by Piaget (1964) as cited in Rafal (2014). This theory posits that, the development of children's brains depends on the environment in which they live and the type of activities they perform. This implies that tools with which children are in contact have a great effect on the development of initiative attitude. Piaget categorized those tools into two; the first are those which do not impose any activity, so a child quickly cease to lose interest in them. The second category are tools that enable diverse activities and arouse creativity. Example of the second category are the building blocks such as LEGO which develops a child's motor skills and attitude. This theory believes that everything we do for children, denies them the opportunity to do it on their own. Thus, the aim of education should base on the passing of task.

This theory can be applied in the school system in that children at early childhood care education are at the preoperative stage in which children become increasingly aware of symbolic thinking, language development, and gradually forming the ability to understand the stability qualities. This implies that human mental development is based on transition from the state of imbalance to balance which is the driving force to make change in the skill and knowledge a child possess. 


\section{METHODOLOGY}

\section{Research Design}

The quantitative research design was used in this study. The design was considered suitable because it will assist the researcher to determine the interaction that exist between digitization and management of early childhood care education. Also the opportunity to acquire opinion of the sample population, analyze the data collected with the use of applicable data analysis technique and reach a sensible conclusion about the population from the findings of the study (Creswell and Creswell, 2017).

\section{Population and Sampling}

This study focused on public primary school with early childhood care education in Northcentral, Nigeria. There are 2,729 public primary schools with early childhood care education in North-central. The target population of this study consisted of 2,729 head teachers and 5,529 teachers in public primary schools with early childhood care education centres in North-central. Sample of 338 head teachers and 361 teachers were selected with the use of Research Advisor (2006) table of determining sample size of a known population. Proportional sampling technique was used to select sample of 338 head teachers and 361 teachers, this involves obtaining the population of head teachers and teachers in each selected primary schools with early childhood care education in North-central and selecting the sample proportionally from these population as shown in table 1. Stratified random sampling technique was used to select head teachers and teachers from the sample schools in order to ensure that all categories of head teachers and teachers were given equal chance of being selected.

Table 1 : Population of Sample Head Teachers and Teachers of Primary School with Early Childhood Education

\begin{tabular}{|c|c|c|c|c|c|}
\hline $\mathbf{S} / \mathbf{N}$ & $\begin{array}{l}\text { North-Central } \\
\text { states }\end{array}$ & $\begin{array}{l}\text { Number of } \\
\text { primary } \\
\text { schools with } \\
\text { early } \\
\text { childhood } \\
\text { education }\end{array}$ & $\begin{array}{l}\text { Number of } \\
\text { teachers }\end{array}$ & $\begin{array}{l}\text { Selected } \\
\text { head } \\
\text { teachers }\end{array}$ & Selected teachers \\
\hline 1 & Benue & 252 & 446 & 31 & 29 \\
\hline 2 & FCT & 132 & 232 & 16 & 15 \\
\hline 3 & Kogi & 574 & 1,167 & 71 & 76 \\
\hline 4 & Kwara & 763 & 941 & 95 & 62 \\
\hline 5 & Nasarawa & 184 & 861 & 23 & 56 \\
\hline
\end{tabular}


$6 \quad$ Niger

7

Plateau

142

1,507

375

5,529

Total

Source: Universal Basic Education Commission (2017)

\section{Instrumentation}

The research instrument for the present study comprised self-constructed titled "Digitization and Management of Early Childhood Care Education Questionnaire" (DMECCEQ) and adapted questionnaire. A total number of 11 items were used to measure digitization with two subscales: collaborative learning (5 items), game-based learning ( 5 items). The items of questionnaire regarding management of early childhood care education were concluded from Abdullahi, Omosidi, Sheu, Abdulkareem (2016) on supervision and regular assessment of learners. It comprised 15 items with two components; supervision (10 items), regular assessment of leaners ( 5 items). Participants responded to five-point Likert scale $(5=$ strongly agree; $4=$ agree; $3=$ neutral; 2 disagree; $1=$ strongly disagree). The criterion mean is given thus: $4+3+2+1 / 4=2.50$. The criterion mean depicts that any item that is above or equal to the criterion mean value of 2.50 is agreed while the one below the criterion mean value is disagreed by the respondent.

\section{Validity and Reliability}

To ensure the content validity of the instrument, draft copies of the instruments were given to two experts in educational management and two experts in measurement and evaluation. Relevant corrections and adjustment were made based on their comments and recommendations. Also 20 corrected copies were further administered to head teachers and teachers who are part of the samples to examine their understanding of the items of the wording, instructions and understandability of the scales and questions in order to detect if there is any difficulty that may arise in filling the questionnaire. Therefore, some suggestion made were effected appropriately before sending out final copies.

To test the reliability of the items, Cronbach's alpha test was used. As shown in Table 2 and 3 , the value for Cronbach's alpha for this study was proven to be reliable.

Table 2 : Reliability test for Digitization

\begin{tabular}{lccc}
\hline Variables & N & $\begin{array}{c}\text { Cronbach's } \\
\text { Alpha }\end{array}$ & Decision \\
\hline Collaborative learning & 6 & 0.82 & All items are reliable \\
Game-based learning & 5 & 0.86 & All items are reliable \\
\hline
\end{tabular}

Table 2 shows that there are 11 items under collaborative learning of digitization. The value of the Cronbach's Alpha for the 6 items under collaborative learning is 0.82 . It further reveals that there are 5 items under game-based learning with Cronbach's Alpha of 0.86. According to Brannen (2017), values above .7 are considered reliable and values above .8 are preferable and represent a good reliability. Therefore, the Cronbach's Alpha value for all the 3 dimensions of ethical leadership were around 0.80 . Therefore, the values shows very good 
internal consistency reliability for scale and all the 25 items in the questionnaire are found to be reliable.

Table 3 Reliability test for Staff innovative Behaviour

\begin{tabular}{llll}
\hline Variables & N & $\begin{array}{l}\text { Cronbach's } \\
\text { Alpha }\end{array}$ & Decision \\
\hline Supervision & 10 & 0.84 & All items are reliable \\
Regular assessment & 5 & 0.86 & All items are reliable \\
\hline
\end{tabular}

Table 3 shows the 2 main indication of management of early childhood care education. These are supervision of pupils, and regular assessment of pupils learning to measure teachers' job performance. The cronbach's value for supervision is 0.84 covering up to 10 number of items. In addition, 5 items from regular assessment has Cronbach's Alpha Value of 0.86. In summary, all instrument items for management of early childhood care education used in this study are reliable for the participants.

\section{Data Collection procedure}

The researcher with the help of six research assistants personally administered the instruments to the head teachers and teachers of the sample primary schools with early childhood care education. The questionnaire was distributed to over 800 respondents consisting of selected head teachers and teachers in public primary schools. These participants were contacted in their respective offices to discuss the basis of the study before the distribution of the questionnaire. After 2 weeks, all the answered questionnaires were collected from the respondents. However, a total of 700 questionnaires were returned and filled properly. Therefore, the returned number meet the suggestion of Research Advisor (2006) with a number of 699 participants sample in this study. Effective administration of questionnaires was also aided by cooperation of colleagues and friends in the sample schools. In the guideline provided by Stanley and Wise (2010), this study emphasized the ethical issues in assuring anonymity and confidentiality of their responses.

\section{Data Analysis}

The data collected for the study were analyzed using descriptive statistics like simple percentage for demographic information and t-test statistical analysis. The data were screened before analysis. Missing data was not an issue in this study because researcher with the help of research assistants administered the questionnaire to the respective participants and made sure the questionnaire is appropriately filled in the process of collection. The research questions were answered using mean and standard deviation while t-test was used to answer the research hypotheses. The $\mathrm{t}$-critical value was compared to the significant level $(0.5)$ to determine the rejection or acceptance of the hypotheses.

\section{Demographic Profile of Respondents}

This section presents a comprehensive result of the analysis made from the data collected in this study. It stated with an analysis of the demographic information of respondents who participated using descriptive statistics 
Table 4: Demographic Profile of the Respondents

\begin{tabular}{l|l|l|l}
\hline & & $\mathrm{N}=699$ & Percentage (\%) \\
\hline Gender: & Female & 559 & $80 \%$ \\
& Male & 140 & $20 \%$ \\
\hline Age: & & 699 & $100 \%$ \\
& $21-30$ & 300 & $43 \%$ \\
& $31-40$ & 162 & $23 \%$ \\
& $41-50$ & 147 & $21 \%$ \\
& 51 above & 90 & $13 \%$ \\
\hline Qualification & & 699 & $100 \%$ \\
& NCE & 389 & $56 \%$ \\
& Bachelor degree & 287 & $41 \%$ \\
& Master degree & 23 & $3 \%$ \\
\hline Year of experience & & & \\
& & 669 & $100 \%$ \\
& $1-5$ years & 134 & $19 \%$ \\
& $6-10$ years & 188 & $27 \%$ \\
& $11-15$ years & 118 & $17 \%$ \\
& $16-20$ years & 120 & $20 \%$ \\
\hline & 21 years above & 139 & $100 \%$ \\
\hline
\end{tabular}

Table 4 shows the demographic information of respondents that participated in this study. From the table 559 respondents $(80 \%)$ are female and 140 respondents are male $(20 \%)$. In terms of average age of the respondents, table 4 presented that majority $300(43 \%)$ are respondents between the age of 21-30, 162 of the respondents $(23 \%)$ are between age 31-40 years, and $147(21 \%)$ of the respondents are between age $41-50$ years as well as 90 of the respondents $(13 \%)$ are over 50 years.

Based on qualification of the respondents, majority 389 respondents $(56 \%)$ are NCE holders, 287 respondents $(41 \%)$ are bachelor degree holders while 23 respondents $(3 \%)$ are master degree holders. In the aspect of year of experience, 134 respondents (19\%) have $1-5$ years of experience, and 188 respondents (29\%) have 6-10 years of experience, majority 118 respondents (17\%) have 11-15 years of experience, there are 126 respondents $(17 \%)$ who have 16-20 years of experience while 139 respondents $(20 \%)$ have over 20 years experience in the sample public primary schools with early childhood care education.

\section{FINDINGS}

This section discusses the result of the findings. The findings were organized based on research objectives. 


\section{Collaborative learning}

\section{Objective 1: Investigate the relationship between collaborative learning and management of early childhood care education.}

Table 5 presents the mean and standard deviation of data collected from 338 head teachers and 361 teachers in public primary schools with early childhood care education in Northcentral, Nigeria. The analysis generated results as shown in Table 5.

Table 5 : Collaborative Learning

\begin{tabular}{|c|c|c|c|c|c|c|}
\hline \multirow[t]{2}{*}{$\mathbf{S} / \mathbf{N}$} & \multirow[t]{2}{*}{ Collaborative Learning } & \multicolumn{2}{|c|}{$\begin{array}{l}\text { Head teachers } \\
\text { Responses }\end{array}$} & \multicolumn{2}{|c|}{$\begin{array}{l}\text { Teachers } \\
\text { Responses }\end{array}$} & \multirow[t]{2}{*}{ Decision } \\
\hline & & Mean & SD & Mean & SD & \\
\hline 1 & $\begin{array}{l}\text { Collaborative learning increases pupils } \\
\text { motivating to learn. }\end{array}$ & 2.98 & 0.929 & 2.87 & 0.948 & Agreed \\
\hline 2 & $\begin{array}{l}\text { Collaborative learning encourage pupils to } \\
\text { make contributions to a group and } \\
\text { experience success. }\end{array}$ & 2.96 & 0.902 & 2.95 & 0.922 & Agreed \\
\hline 3 & $\begin{array}{l}\text { Collaborative learning help learner gain } \\
\text { access to peer. }\end{array}$ & 2.95 & 0.949 & 2.96 & 0.945 & Agreed \\
\hline 4 & $\begin{array}{l}\text { Collaborative learning help learner to be } \\
\text { more productive. }\end{array}$ & 3.04 & 0.946 & 2.90 & 0.996 & Agreed \\
\hline \multirow[t]{2}{*}{5} & $\begin{array}{l}\text { Learners gain more knowledge by working } \\
\text { with peers }\end{array}$ & 2.93 & 0.966 & 2.96 & 0.951 & Agreed \\
\hline & Grand Mean & 2.97 & 0.938 & 2.93 & 0.952 & \\
\hline
\end{tabular}

(Mean $\geq 2.50$ Agree, Mean $<2.50$ Disagree)

As shown in Table 5, the overall mean for head teachers and teachers' perception on collaborative learning is $2.97(\mathrm{SD}=0.938)$ and $2.93(\mathrm{SD}=0.952)$ respectively. This could be interpreted that participants agreed that collaborative learning enhance effective management of early childhood care education. The results of the analysis for each collaborative learning indicated that two out of five collaborative learning showed higher mean than the grand mean value. The items are collaborative learning increases pupils motivating to learn $(M=2.98$, $S D=0.929)$ and $(M=2.87, S D=0.948)$, followed by collaborative learning help learner to be more productive $(M=3.04, S D=0.946)$ and $(M=290, S D=0.996)$,

However, the other three items - collaborative learning encourage pupils to make contributions to a group and experience success $(M=2.96, S D=0.902)$ and $(M=2.95, S D=$ $0.922)$, collaborative learning helps learners gain access to peers $(M=2.95, S D=.949)$ and $(M=2.96, S D=.945)$ and learners gain more knowledge by working with peers $(M=2.93$, $S D=0.966)$ and $(M=2.96, S D=0.951)$ showed lower mean than the grand mean of collaborative learning. Meanwhile, all five items of collaborative learning have mean values 
(2.97) and 2.93 that are interpreted as agreed. This revealed that participants agreed that collaborative learning enhance effective management of early childhood care education in North-central.

\section{Game-Based Learning}

The second research objective is about relationship between game-based learning and management of early childhood care education as shown in the following:

Table 6: Game-Based Learning as Responded by Head Teachers and Teachers

\begin{tabular}{|c|c|c|c|c|c|c|}
\hline \multirow[t]{2}{*}{$\mathbf{S} / \mathbf{N}$} & \multirow[t]{2}{*}{ Game-Based Learning } & \multicolumn{2}{|c|}{$\begin{array}{l}\text { Head Teacher } \\
\text { Responses }\end{array}$} & \multicolumn{2}{|c|}{$\begin{array}{l}\text { Teachers } \\
\text { Responses }\end{array}$} & \multirow[t]{2}{*}{ Decision } \\
\hline & & Mean & SD & Mean & SD & \\
\hline 6 & $\begin{array}{l}\text { Game-based learning help learner to have } \\
\text { better self-management. }\end{array}$ & 2.93 & 0.961 & 2.88 & 0.940 & Agreed \\
\hline 7 & $\begin{array}{l}\text { Game-based learning offer opportunities for } \\
\text { collaboration and inquiry-based learning. }\end{array}$ & 2.98 & 0.921 & 3.02 & 0.886 & Agreed \\
\hline 8 & $\begin{array}{l}\text { Game-based learning improve self-directed } \\
\text { learning. }\end{array}$ & 2.94 & 0.965 & 2.97 & 0.954 & Agreed \\
\hline 9 & $\begin{array}{l}\text { Game-based learning give support skill } \\
\text { development that learners need in learning. }\end{array}$ & 2.89 & 1.014 & 3.00 & 0.950 & Agreed \\
\hline \multirow[t]{2}{*}{10} & $\begin{array}{l}\text { Game-based learning help drive learners } \\
\text { engagement in learning. }\end{array}$ & 2.87 & 1.012 & 3.02 & 0.925 & Agreed \\
\hline & Grand Mean & 2.92 & 0.975 & 2.98 & 0.931 & \\
\hline
\end{tabular}

(Mean $>2.50$ Agree, Mean $<2.50$ Disagree). Researcher field work

The second research objective is about game-based learning as shown in Table 6, the grand mean for head teachers and teachers on game-based learning is $2.92(\mathrm{SD}=0.975)$ and 2.98 $(\mathrm{SD}=0.931)$ respectively. This could be inferred that participants agreed that game-based learning improve effective management of early childhood care education. The analysis for each game-based learning items indicated that three out of five game-based showed higher mean than grand mean value. The items are game-based learning help learner to have better self-management $(M=2.93, S D=0.961)$ and $(M=2.88, S D=0.940)$, followed by gamebased learning offer opportunities for collaboration and inquiry-based learning $(M=2.98$, $S D=00.921)$ and $(M=3.02, S D=0.886)$, and game-based learning improve self-directed learning $(M=2.94, S D=0.965)$ and $(M=2.97, S D=0.954)$.

Meanwhile, the other two items - game-based learning give support skill development that learners need in learning $(M=2.89, S D=1.014)$ and $(M=3.00, S D=0.950)$ and gamebased learning help drive learners engagement in learning $(M=2.87, S D=1.012)$ and $(M=$ $3.02, S D=0.925)$ showed lower mean than the grand mean of game-based learning. Therefore, all five items of game-based learning have the mean values (2.92) and (2.98) that are higher than criterion mean of 2.50 . This shows that the participants agreed that game- 
based learning improve effective management of early childhood care education in Northcentral.

\section{Hypotheses Testing}

T-test statistical analysis was used in this study to test the set hypotheses as follow:

H01: there is no significant difference between the mean scores of head teachers and teachers on collaborative learning and management of early childhood care education.

Table 7: Collaborative Learning and Management of Early Childhood Care Education

\begin{tabular}{llllllll}
\hline Variable & $\mathbf{N}$ & $\overline{\boldsymbol{x}}$ & SD & Df & Tcal & t-crit & Decision \\
\hline Head teachers & 338 & 2.97 & 0.938 & & & & \\
& & & & 697 & 1.29 & 1.96 & Accepted \\
Teachers & 361 & 2.93 & 0.952 & & & & \\
\hline
\end{tabular}

Table 7 indicates the t-test analysis between the mean scores of head teachers' and teachers' responses on collaborative learning and management of early childhood care education. The $\mathrm{t}$-calculated value of 1.29 is less than t-critical value of 1.96. This means there is no significant difference between the responses of head teachers and teachers on collaborative learning and management of early childhood care education. Therefore, the hypothesis which states that there is no significant difference between collaborative learning and management of early childhood care education is accepted.

Ho2: There is no significant difference between the mean scores of head teachers and teachers on game-based learning and management of early childhood care education.

Table 8: Game-based Learning and Management of Early Childhood Care Education.

\begin{tabular}{llllllll}
\hline Variable & $\mathbf{N}$ & $\overline{\boldsymbol{x}}$ & SD & Df & Tcal & $\boldsymbol{t}$-crit & Decision \\
\hline Head teachers & 338 & 2.92 & 0.975 & & & & \\
& & & & 697 & 1.05 & 1.96 & Accepted \\
Teachers & 361 & 2.98 & 0.931 & & & & \\
\hline
\end{tabular}

Table 8 indicates the t-test analysis between the mean scores of head teachers' and teachers' responses on game-based learning and management of early childhood care education. The tcalculated value of 1.05 is less than t-critical value 1.96. This means there is no significant difference between the responses of head teachers and teachers on game-based learning and management of early childhood care education. Therefore, the null hypothesis which states that there is no significant difference between game-based learning and management of early child hood care education is accepted.

\section{DISCUSSION}

The result of question one analysis and findings in Table 5 shows that collaborative learning enhances effective management of early childhood care education in Northcentral zone, such that it increases pupils' motivation to learn, encourage pupils to make contributions to a group and experience success, helps learners gain access to their peers, 
helps learners to be more productive as well as helping learners gain more knowledge by working with peers. Results from hypothesis one revealed that there is no significant difference between collaborative learning and management of early childhood care education in North-central, Nigeria. This findings conformed to Nilufer (2016) that collaborative learning methods are more effective on the pupils' success compared to traditional methods of teaching. This findings agreed with Dewiyanti, Brand-Gruwel, Jochems and Broers (2007), that collaborative learning influence learners' satisfaction and positive experiences. This finding also concurs with the finding of Noorul and Masitah (2015) that collaborative learning assists learners in gaining more knowledge and learn specific skills. The findings of this study was consistent with previous research (Anna, Konrad, \& Magnus, 2019) which concluded that digitization provides meaningful learning task in preschool learning environment. This findings in line with Chan (2004) that collaborative learning is effective on the preschool children because it improves their listening skills, verbal explanation skills and interpretation skills.

The findings in Table 6 show that game-based learning improve effective management of early childhood care education in North-central, Nigeria. These are, game-based learning helps learners to have better self-management, offer opportunities for collaborative and inquiry-based learning, improve self-directed learning, support skill development that learners need in learning as well as drives learners engagement in learning. Result from hypothesis two analysis showed that there is no significant difference between game-based learning and management of early childhood care education. The findings of this study is in line with Wemhuar and Weichian (2010) that game-based learning system can enhance learners' learning in the school. This findings conformed to Ching-Hsue and Chung-Ho (2012) that learning achievements of students with game-based learning are better than those who use the traditional method of teaching. This findings agreed with Ming-Hung, Huanh-Cheng and Kuang-Sheng (2019) that digital learning brings about positive effects on learning outcome.

\section{IMPLICATIONS AND CONCLUSION}

The findings of this study will be of great advantage to head teachers, teachers, government and stakeholders in education. The findings of this study will help head teachers and teachers to effectively go into digitization of education to make use of appropriate methods of teaching toward the realization of educational goals and objectives. This finding will also be of great benefit to government and stakeholders to formulate policies that will encourage digitization of education in order to bring about standardized curriculum for effective management of early childhood care education. Researchers will also benefit from the outcome of this study in that it will lay a good basis for further research.

Early childhood care education is the foundation of all education system that provide solid ground for future country development. To achieve, the aim of this education, digitization of education system needs to be put in place. This findings show that the key to effective management of early childhood care education is the promotion of digital learning in preschool education which could provide alternative innovation to classroom teaching. Further researches can expand this study by using other variables apart from collaborative learning and game-based learning as indices of digitization of education system. Also, the study can be carried out in primary, secondary and post-secondary school education. 


\section{RECOMMEDATIONS}

Teachers should continue to make use of collaborative learning in order to increase pupils' motivation to learn, encourage pupils to make contributions to a group and experience success, help learner gain access to peer, help learners to be more productive as well as help learners gain more knowledge by working with peers. Teachers should also make use of appropriate game-based learning for learners to have better self-management, opportunities for collaborative and inquiry-based learning, improving self-directed learning, supporting skill development that learners need in learning as well as driving learners engagement in learning in order to enhance effective management of early childhood care education.

\section{REFERENCES}

Abdullahi, N. J. K. (2017). Era of economic recession and Management of universal basic education. Malaysian Online Journal of Educational Management, 5(3), 32-40.

Abdullahi, N. J. K., Omosidi, A. S., Sheu, A. A., \& Abdulkareem, R. L. (2016). Head teacher supervision and teachers' job performance in public primary schools in Kwara State, Nigeria. Journal of Humanities and Education, 1(1), 41-49.

Abdullahi, O. E. (2016). Principles of classroom evaluation. Introduction to teaching methodology. In A. A. Adegoke, R. A. Lawal, A. G. A. S. Oladosun \& A. A. Jekayinfa (Eds.). Haytee Press and Publishing Company Ltd, Ilorin, Kwara State, Nigeria.

Anna, O., Konrad, S., \& Magnus, H. (2019). Surveying preschool teachers' use of digital tablets: General and technology education related findings. International Journal of Technology and Design Education, 29(4), 717-737.

Brannen, J. (2017). Mixing methods: Qualitative and quantitative research. Retrieved from https://www.taylorfrancis.com/books/9781351917186

Chan, K. W. (2014). Cooperative learning in a Hong Kong primary school: Perception, problems and recommendation. Intercultural Education, 25(3), 216-228.

Ching-Hsue, C., \& Chung-Ho, S. (2012). A game-based learning system for improving student's learning effectiveness in system analysis course. Procedia-Social and Behavioural Sciences, 31, 669-675

Cloonan, M. V., \& Sanett, T. (2005). The preservation of digital content. Libraries and Academy, 5(2), 213-237.

Colombo, M. (2016). Introduction to the special sector. The digitization of educational practices: How much and What Kind. Italian Journal of Sociology of Education, 8(2), 1-10.doi:10.14658/pupj-ijse-2016-2-1

Connolly, M. T., Boyle, A. E, MacArthur, E, Hainey, T, \& Boyle, M. J. (2012). A systematic literature review of empirical evidence on computer games and serious games. Computer and Education, 59(2), 661-686.

Creswell, J. W., \& Creswell, J. D. (2017), Research design: Qualitative, and mixed methods approaches. USA: Sage Publications.

Dewiyati, S., Brand-Gruwel, S., Jochems, W., \& Broers, N. (2007). Students' experiences with collaborative learning in a synchronous computer-supported collaborative learning environments. Computer in Human Behaviour, 23, 496-514.

Falasteen, N. (2018). The implementation of digitalization system in education in Palestine. International Journal for Information, 11(2), 1749-1754.

Federal Republic of Nigeria. (FRN) (2013). National policy on education: Federal Ministry of Education. Yaba, Lagos - Nigeria.

Gillies, R. M. (2006). Teachers and students' verbal behaviour during cooperative learning and small group learning. British Journal of Educational Psychology, 76(2), 271-282. http://dx.doi.org/10.1348/000709905x52337

John, I. N. (2014). Theories and principles of management in education. Management in Education: Modern Approaches in Educational Management. Giraffe books, Ibadan, Oyo State, Nigeria.

Lin, E. (2006). Cooperative learning in the science classroom. The Science Teacher, 73(5), 34-39.

Ming-Hung, L., Huang-Cheng, C., \& Kuang-Sheng, L. (2019). A study of the effects of digital learning on Learning motivation and learning outcome. EURASIA Journal of Mathematics Science and Technology Education, 13(7), 3553-3564.

Nilufer, O. A. (2016) implementation of cooperative learning method in preschool. Journal of Education and Learning, 5(3), 83-93. 
Noorul, D. S., \& Masitah, S. (2015). Collaborative learning to develop students' skills of the 21 century. Mediterranean Journal of Social Sciences, 6(4), 543-552.

Olga, N. M. (1017). Digitalization of education as a trend of its modernization and reforming. Revista Espacios Journal, 38(40), 26-30.

Owolabi, H. O. (2016). Evaluation in the practice of teaching. Introduction to teaching methodology. In A. A. Adegoke, R. A. Lawal, A. G. A. S. Oladosun \& A. A. Jekayinfa (Eds.). Haytee Press and Publishing Company Ltd, Ilorin, Kwara State, Nigeria.

Petersen, P. (2015). That is how much I can do: Children agency in digital tablet activities in a Swedish preschools environment. Nordic Journal of Digital Literacy, 10(3), 145-169.

Phaik, K. C., \& Ahmad, M. M. (2012). Education policy: A case study of digitizing education in Malaysia. Procedia Social and Behavioural Sciences, 69, 1714-1718.

Piaget, J. (1964). Congnitive development in children: Piaget development and learning. Journal of Research in Science Teaching, 2(3), 176-186.

Premiumtimesng.com (March 19, 2013). Retrieved from www.premiumtimesng.com 10/07/2019.

Rafal, W. (2014). A study of the impact of technology in early education. Thesis submitted to Uppsala University. Retrieved from pdfs. sematicscholar.org/82cc/9dod7833615ff8986boc11d30b208a49f76b.pdf. 06/07/2019.

Rasmi, R. P., Swagakika, R., \& Sunakar, D. (2019). Pre-primary: Its impact on academic achievement of the learners learning at an elementary stage in Odia. International Journal of Management Science and Business Administration, 5(3), 36-42.

Research Advisor (2006). Sample size table. http://www.research-advisor.com

Segun, O. (2010). Nature and purpose of educational management. The Craft of educational management. In F. Durosaro and S. Ogunsaju (Eds). Indemac print media, Kwara State, Nigeria

Sheu, A. A., \& Ijaiya, N. Y. S. (2006). Influence of resource availability on teachers' job performance in early childhood education. Malaysian Online Journal of Educational Management, 4(4), 37-49

Stanley, L., \& Wise, S. (2010). The ESRC's 2010 Framework for Research Ethics: fit for research purpose? Sociological Research Online, 15(4), 12-13.

Wemhuar, T., \& Weichian, T. (2010). The design and analysis of learning effects for a game-based learning system. International Journal of education and Pedagogical Sciences, 4(1), 14-23.

Yousafzai, A. K., Rasheed, M. A., Rizvi, A., Shaheen, F., Ponguta, L. A., \& Reyes, C. R. (2018). Effectiveness of a youth-led early childhood care and education programme in rural Pakistan: A cluster-randomized controlled trial. Plos One Journal, 13(12), 1-14. 